\title{
GUEST SATISFACTION SURVEY AT THE AQUATICUM DEBRECEN THERMAL AND WELLNESS HOTEL
}

\author{
Gábor Hevessy \& Katalin Vargáné Csobán
}

\author{
University of Debrecen, Centre for Agricultural and Applied Economic Sciences, Faculty of Applied Economics \\ and Rural Development, Institute of Rural Development and Functional Economics, \\ Department of Tourism and Catering Management \\ E-mail: hevessy@aquaticum.hu \\ H-4032 Debrecen, Böszörményi út 138, Tel: +36-52-526-960, Fax: +36-52-526-964
}

\begin{abstract}
Aquaticum Debrecen Thermal and Wellness Hotel is one of the most successful hotels in the North Great Plains region as well as in Hungary. The key to success lies in high level customer satisfaction. On the one hand only the satisfied guests will return to the hotel, on the other hand the guests' positive or negative opinions will be shared with thousands of potential customers immediately by means of the Internet. Consequently, exploring the main factors of guest satisfaction has never been so important as nowadays. An online questionnaire system was introduced to the hotel in 2010, which resulted in an increased number of customer responses, thus it became possible to analyse the various aspects of customer satisfaction in a greater detail. In the present study the critical factors of guest satisfaction are analysed. We investigated the guests' willingness to return to the hotel, and found that there is no significant difference between the guests' gender, age, permanent place of residence and the fact if they travel alone or with a company and their willingness to return to the hotel, i.e. guest satisfaction. However, business travellers' opinion significantly differs from the recreational travellers' views concerning their return to the hotel. Business travellers are less satisfied and less willing to return. Furthermore, we investigated whether the problems experienced by the guests in the hotel influence the guests' willingness to return to the hotel. We found that the guests who experienced problems are less willing to return. However, we also concluded that there was no significant difference in their willingness to return among those guests who experienced problems during their stay and these were efficiently handled, and those guests who did not experience any problem.
\end{abstract}

Key words: hotel, Aquaticum, questionnaire, guest satisfaction

\section{Introduction}

In the present study we are going to analyse the results of the guest satisfaction survey which was conducted in the Aquaticum Debrecen Thermal and Wellness Hotel between 25th August 2010 and 31st January, 2011. The four-star Aquaticum Debrecen Thermal and Wellness Hotel is situated in the first nature conservation area of Hungary, the recreational area of Debrecen, in the heart of Great Forest of Debrecen. The hotel is located in Aquaticum Medical and Bathing Centre, where thermal baths, outdoor pools, the indoor Mediterranean Pleasure Baths, a medical department, a wellness island, a Thai massage centre, a dental centre and restaurants offering Hungarian specialties offer complex services to the hotel guests.

In the air-conditioned hotel there are 56 double rooms and 40 apartments. The hotel is directly connected to the Mediterranean Adventure Spa via a heated corridor, which is a unique feature of the hotel. These days the hotel and the spa is a popular destination for the families with children.
On 25th August, 2010 a new internet-based questionnaire was introduced to the Aquaticum Thermal and Wellness Hotel. Those guests who submit their e-mail address to the hotel upon arrival will receive an online guest satisfaction survey one week after their check-out. The number of the completed questionnaires grew tenfold compared to the number of previously used paper-based questionnaires after the online survey had been introduced.

The aim of our research is to determine the critical factors that influence guest satisfaction and the guests' willingness to return.

\section{Materials and methods}

In the analysis 1103 questionnaires were included, which were completed by the hotel guests aged 18 and older between 25th August 2010 and 31st January, 2011. The questionnaires were not sent out to people under 18 years of age. Out of the 1103 questionnaires 40 were only 
partially, while 1063 were fully completed, thus the exit rate was $3.6 \%$. The answers of the respondents who did not fully complete the questionnaires were taken into consideration, as well. The respondents could skip questions according to their previous answers. For these reasons the total number of the respondents is not constant at each question, consequently it varies in the sample, too. During the survey period the number of the guests aged 18 and older was 4074 at the hotel, $52.6 \%$ of them (2142 people) submitted their e-mail address at the check-in. $51.5 \%$ of the ones who gave their e-mail address completed the questionnaires, which represents $27 \%$ of the population. After the primary datacollection statistical analysis was carried out by using the SPSS statistical software and the Microsoft Excel program.

The guests could express their opinion using a 5-point rating scale, where " 1 "equals the worst while "5" equals the best opinion. According to the statistical literature the scale we used can be regarded as an ordinal scale. (Blaskovits 1975; Huzsvai 2004) When exploring the related scientific literature we have found that this is the most widely used scale in tourism perception studies. (Tatoglu et al. 2002; Pizam et al. 2000; Lawton 2005; Haley et al. 2005; Ramchander 2004) The 1-to-5 rating scale provides an effective method for measuring the performance and analysing the data by the statistical methods used in the above mentioned studies if we accept the presupposition that the respondents regard the distances between the different ratings as equal. If this presupposition is accepted these scales can be treated as interval scales in the analysis. (Blaskovits 1975 cited by Lehota 2001)

The ordinal scale we have used is generally treated as an interval scale, for example when calculating the mean value of the students' marks in the schools. Several test theories, eg. the ones used in psychology to test attitudes and abilities follow the assumption that these scales are interval scales even if it cannot be empirically proven. (Horváth 1993) We have followed this assumption and treated our scale as an interval scale during the analysis.

\section{Results and discussion}

\section{Demographic characteristics of the respondents}

Figure 1 demonstrates the distribution of guests in the sample according to gender, while figure 2 shows the distribution according to age. $44.5 \%$ of the respondents were male $(n=473)$, while $55.5 \%$ were female $(n=590)$.

As Figure 2 shows the primary target group of the hotel is the age group between 25 and 44 years of age. These guests usually stay with their children at the hotel.

Figure 3 illustrates the distribution of the respondents according to their place of residence.

It can be clearly seen that the vast majority of the guests arrive from Budapest and the surrounding area. The numbers indicate that $67.1 \%$ of the respondents live in this region.

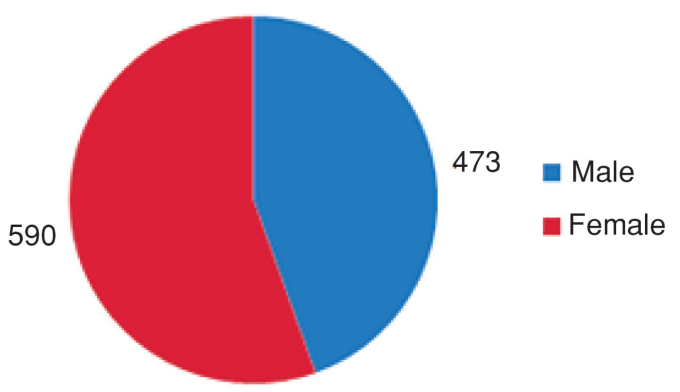

Figure 1. The distribution of the respondents according to gender Source: Own database

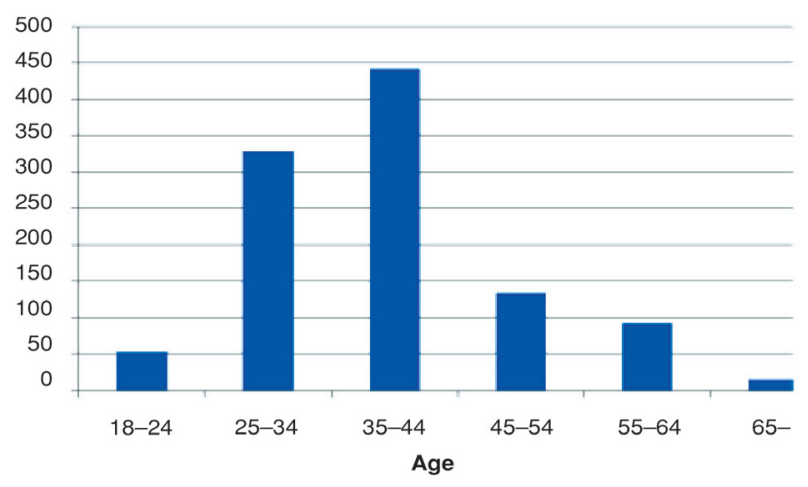

Figure 2. The distribution of the respondents according to age Source: Own database

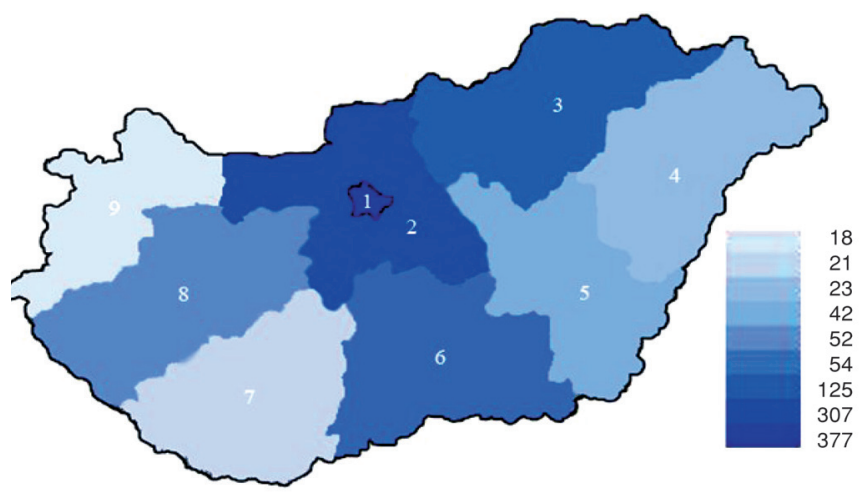

Figure 3. The number of guests according to their premanent address Source: Own database

\section{Marketing-based data}

The first question of the guest satisfaction questionnaire was meant to find out whether the respondent was a returning guest. The answers indicate that $45.2 \%(n=499)$ had previously stayed at the hotel, while $54.8 \%(\mathrm{n}=604)$ were first-time guests. (Figure 4)

Most of the returning guests had already stayed 2-4 times at the hotel. (Figure 5)

The vast majority of the respondents stated that "holiday and recreation" were their main motives of travel (89.3\%), only $10.7 \%$ identified themselves as business travellers. (Figure 6)

The respondents were also asked where they travelled alone or with a partner/family. As Figure 7 illustrates most of the guests stayed with their family at the hotel but the number of guests travelling with their partner is rather significant, too. (Figure 7) 


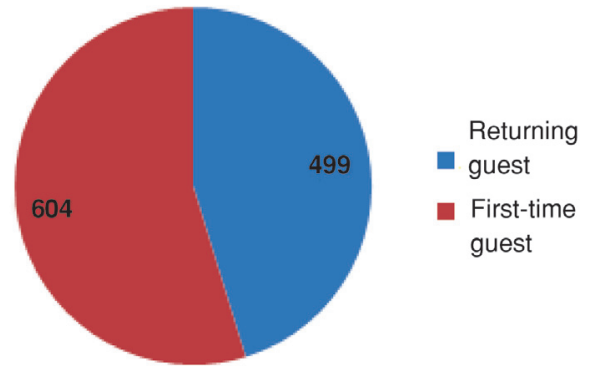

Figure 4. The distribution of the returning and first-time guestsSource: Own database

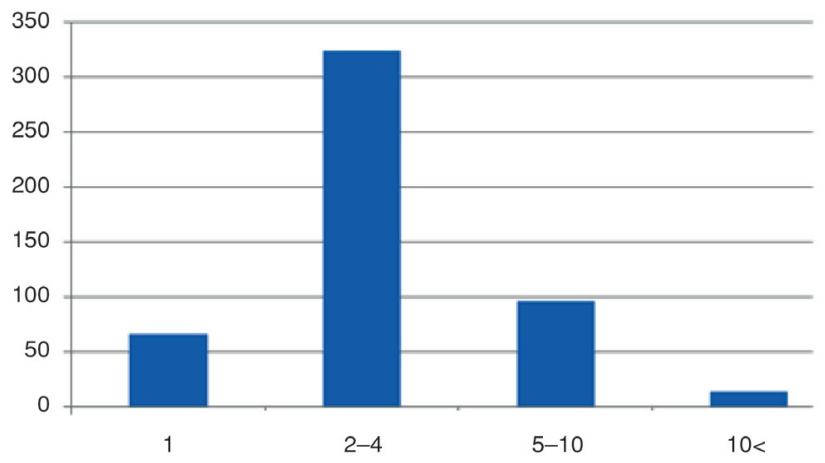

Figure 5. The number of previous visits among the returning guests Source: Own database

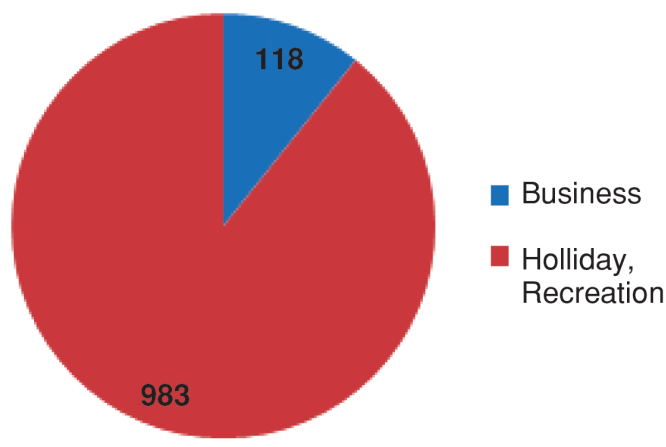

Figure 6. The main travel motives of the respondents Source: Own database

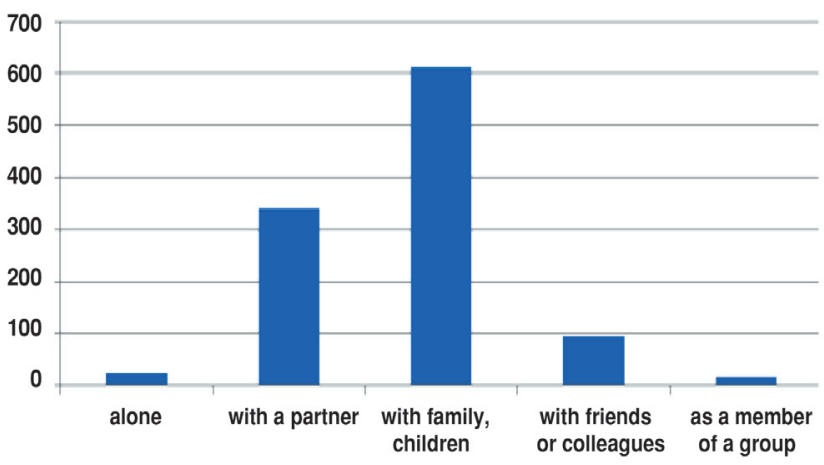

Figure 7. The distribution of guests according to the fact that they travel alone or with anyone else Source: Own database

\section{Investigation of guest satisfaction in relation to demographic characteristics and travel motives}

Guest satisfaction is closely related to the guests' willingness to return to the hotel (Marriott 1997) and their willingness to recommend the hotel to their friends and relatives. If a hotel continously measures the guests' satisfaction and is able to increase satisfaction by appropriate measures, guests' willingness to return, their loyalty will consequently increase. (Temkin 2009)

For this reason we regarded the guests' willingness to return as the measure of their satisfaction and investigated its main characteristics. First of all, we investigated whether the willingness to return to the hotel differs among male and female guests. According to the null hypothesis there is no significant difference among males and females in their willingness to return. (In the analysis the significance level was 5\%) Two sample t-test was used to test the hypothesis, On the basis of the test results it can be concluded that there is no significant difference between the male and female guests in their willingness to return.

Secondly, we have investigated whether the willingness to return varies with the age of the guests. According to the null hypothesis there is no significant difference among the various age-groups in their willingness to return. The one-way ANOVA test was used in the analysis. The results of Levene's test were not significant, thus the population variances are equal. Based on the ANOVA test the null hypothesis must be accepted, which implies that the guests' willingness to return does not differ in the various age-groups. Moreover, we have not found a significant difference in the guests' opinion, which would reflect the region where they otherwise live.

We have also investigated if there is a significant difference among the groups of guests depending on the fact that they stay alone at the hotel or with a partner/family/friends or colleagues. Based on the results of the ANOVA test we can conclude that there is no significant difference in this respect either.

As far as the travel motives are concerned the guests who stay at the hotel travel either for recreational or business purposes. According to the null hypothesis there is no significant difference depending on the guests' travel motives. We have used a two-sample t-test to test this hypothesis. Based on the results, this hypothesis must be rejected, as there is a significant difference in the guests' willingness to return: the guests who travel for recreational purposes are more satisfied and they are more willing to return.

\section{Investigation of guest satisfaction relating to the efficiency of handling the guests' complaints}

In the online questionnaire we also enquired whether the guests experienced any problem during their stay at the hotel. Our investigation showed that there is a significant difference in their willingness to return among those guests who experienced problems compared to the ones who did not. 
Obviously, the guests who did not experience any problem were more willing to return.

If the guest had a problem and reported it to the hotel during the stay, we asked how satisfied he/she was with the handling of the complaint. We used a scale for the evaluation, where "5" indicated ,very satisfied" while "1" meant "utterly dissatisfied". The figure below illustrates the means of the "marks" given for the handling of the guests' complaints. (Figure 8)

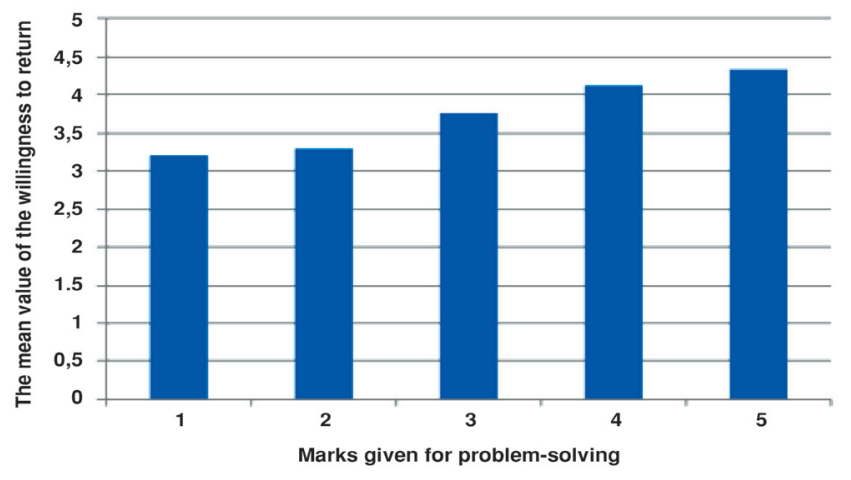

Figure 8. Willingness to return and the efficiency of handling the complaint Source: Own database

It is worth noting that if the guest's problem was efficiently handled (marked as "4" or "5" by the guest), the guest's willingness to return is high (above "4"). Consequently, we have examined if there is a significant difference in their willingness to return among those guests whose problem was efficiently solved (mark "5") and those guests who did not experience any problem at the hotel at all.

It can be concluded that there is no significant difference in their willingness to return among those guests who experienced problems during their stay and these were efficiently handled and those guests who did not experience any problem at all.

\section{Conclusion}

There is a positive correlation between guest satisfaction and their willingness to return to the same hotel according to the scientific literature. Satisfied guests are more willing to return, as well as the ones who claim that they will probably return were definitely satisfied with the hotel services. On these grounds we investigated the guests' willingness to return to the hotel, and found that there is no significant difference between the guests' gender, age, permanent place of residence and the fact if they travel alone or with a company and their willingness to return to the hotel, ie. guest satisfaction. However, business travellers' opinion significantly differs from the recreational travellers' views concerning their return to the hotel. Business travellers are less satisfied and less willing to return.

In the second part of our study we investigated whether the problems experienced by the guests in the hotel influence the guests' willingness to return to the hotel. Not surprisingly we found that the guests who experienced problems are less willing to return. However, we also concluded that there was no significant difference in their willingness to return among those guests who experienced problems during their stay but these were efficiently handled and those guests who did not experience any problem. It has highly important practical implications for the hotel management as it highlights the outstanding significance of complaint management.

\section{References}

Blaskovits, L. (1975): Kérdés-kérdőív-megkérdezés a piackutatás gyakorlatában (Question - Questionnaire - Querying in the Practice of Market Research), Közgazdasági és Jogi Könyvkiadó, Budapest, 251 p., ISBN 9632201833

Haley, A.J., Snaith, T., Miller, G. (2005): The social impacts of tourism a case study of Bath, UK, Annals of Tourism Research, Volume 32, Issue 3, July 2005, Pages 647-668.

Horváth, Gy. (1993): Bevezetés a tesztelméletbe (Introduction to Test Theory), Keraban Kiadó, Budapest, ISBN 9638146060

Huzsvai, L. (2004): Biometriai módszerek az SPSS-ben (Biometrical Methods in SPSS), Debreceni Egyetem, Mezőgazdaságtudományi Kar, p.131.

Lawton, L.J. (2005): Resident Perceptions of Tourist Attractions on the Gold Coast of Australia, Journal of Travel Research, Vol. 44, No. 2, pp.188-200.

Lehota, J. (2001): Marketingkutatás az agrárgazdaságban (Marketing Research in Agroeconomics), Mezőgazda Kiadó, Budapest, 233p., ISBN 9639358258

Marriott J.W. (1997): The Spirit to Serve, HarperCollins, New York, ISBN 9780887309915

Pizam, A., Uriely, N., Reichel, A. (2000): The intensity of touristhost social relationship and its effects on satisfaction and change of attitudes: the case of working tourists in Israel, Tourism Management, Volume 21, Issue 4, pp. 395-406.

Ramchander, P. (2004): Towards the Responsible Management of the Socio-Cultural Impact of Township Tourism - Philosophiae Doctor Thesis of Ramchander Pranill, University of Pretoria

Tatoğlu, E., Erdal, F., Özgür, H., Azakli, S. (2002): Resident Attitudes Toward Tourism Impacts: The Case of Kusadasi in Turkey, International Journal of Hospitality and Tourism Administration (IJHTA), Vol 3, No. 3, pp. 79-100.

Temkin B.D. (2009): Customer Experience Correlates to Loyalty, Forrester Research Inc. 